\title{
KEPALSUAN HUKUM \\ DALAM PENANGANAN KORUPSI DI INDONESIA PADA MASA PEMERINTAHAN SUSILO BAMBANG YUDHOYONO
}

\author{
Rina Khairani Pancaningrum \\ Fakultas Hukum, \\ Universitas Mataram \\ Nusa Tenggara Barat (NTB) Indonesia \\ Email: rinahukum@gmail.com
}

\begin{abstract}
False Law in the handling of Corruption in Indonesia in the era of Susilo Bambang Yudhoyono describes the law enforcement conditions that have not been maximized so as to reduce public confidence in the government's performance at that time, this journal aims to know the picture of handling corruption in the era of Susilo Bambang Yudhoyono; This journal uses the normative juridical method. While the analysis with qualitative methods. The result of this paper is the condition of keos which is caused by the falsity of law in handling corruption in Indonesia in the era of Susilo Bambang Yudhoyono government, is not something to be feared or avoided or resisted by antipathy. But the first and most important step to build public trust is to "change the legal paradigm from the formal paradigm to the substantial paradigm."
\end{abstract}

Keywords: Corruption, Counterfeit, paradigm

Abstrak: Kepalsuan Hukum dalam penanganan Korupsi di Indonesia pada era Susilo Bambang Yudhoyono menggambarkan kondisi penegakan Hukum yang belum maksimal sehingga menurunkan kepercayaan masyarakat terhadap kinerja pemerintah di zaman itu, Jurnal ini bertujuan untuk mengetahui gambaran penanganan korupsi di era Susilo Bambang Yudhoyono; Jurnal ini menggunakan metode yuridis normative. Sedangkan analisis dengan metode kualitatif. Adapun hasil dari tulisan ini adalah Kondisi keos yang ditimbulkan oleh kepalsuan hukum dalam penanganan korupsi di Indonesia pada era pemerintahan Susilo Bambang Yudhoyono, bukanlah sesuatu yang harus ditakuti atau dihindari atau dilawan dengan antipati. Tetapi langkah yang paling pertama dan utama untuk membangun kepercayaan masyarakat adalah dengan melakukan "perubahan paradigma hukum dari paradigma formal ke paradigma substansial."

Kata kunci: Korupsi, Kepalsuan, paradigma

\section{LATAR BELAKANG}

Pada masa pemerintahan Presiden Soeharto yang berlangsung selama lima dekade (1966-1998) atau Orde Baru, pemerintah menyatakan akan menjalankan UUD 1945 dan Pancasila secara murni dan konsekuen. "Namun kenyataannya dilaksanakan menyimpang dari Pancasila dan UUD 1945 yang murni, terutama pelanggaran Pasal 23 (hutang Konglomerat/private debt dijadikan beban rakyat Indonesia/public debt) dan Pasal 33 UUD 1945 yang memberi 


\section{Regal Revieu}

kekuasaan pada pihak swasta untuk menghancurkan hutan dan sumber alam kita."

Mengutip pernyataan Nonet dan Selznick bahwa "hukum in action tidak selalu sejalan dengan yang ditulis dalam teks, bahkan ada kecendrungan ke arah inkonsistensi"2 . Hukum in action sudah berwajah jamak, atau "hukum dalam kenyataannya tidak tampak secara hitam putih"3. "Berakhirnya masa jabatan Presiden Soeharto juga tidak melalui suatu proses hukum tata negara yang formal, melainkan secara mendadak di luar hukum." Mendadak karena Presiden Soeharto dituntut turun melalui pergerakan mahasiswa yang menduduki gedung senayan pada tahun 1998 sebagai awal gerakan reformasi.

Reformasi dilakukan sebagai salah satu agenda nasional yang menuntut "dilakukannya perubahan (amandemen) UUD 1945" . Latar belakang tuntutan perubahan UUD 1945 antara lain karena "pada masa Orde Baru, kekuasaan tertinggi di tangan MPR (bukan di tangan rakyat), kekuasaan yang sangat besar pada Presiden, adanya pasal-pasal yang terlalu 'luwes' (sehingga dapat menimbulkan multitafsir), serta kenyataan rumusan UUD 1945 tentang semangat penyelenggara negara yang belum cukup didukung ketentuan konstitusi"”.

Tujuan perubahan UUD 1945 waktu itu adalah menyempurnakan aturan dasar seperti tatanan negara, kedaulatan rakyat,

\footnotetext{
${ }^{1}$ Wikipedia Bahasa Indonesia, Ensiklopedia Bebas (1), Undang-Undang Dasar Republik Indonesia 1945, http://id.wikipedia.org/wiki/UndangUndang_Dasar-Republik-Indonesia-1945, Diakses 23 April 2009.

${ }^{2}$ Satjipto Rahardjo, "Sisi-Sisi Lain dari Hukum di Indonesia", Kompas, (2006): xiv.

${ }^{3}$ Ibid., hlm. xvi.

4 Satjipto Rahardjo, Biarkan Hukum Mengalir Catatan Kritis tentang Pergulatan Manusia dan Hukum, Kompas, (2008): 98.

5 Jimly Asshiddiqi, Bagir Manan, dkk, Gagasan amandemen UUD 1945 dan Pemilihan Presiden Secara Langsung, (Jakarta: Setjen \& Kepaniteraan MKRI, Jakarta, 2006) hlm. vi.

${ }^{6}$ Wikipedia Bahasa Indonesia, Op.Cit.,
}

Issn cetak 2597.9353 Issn online 2580.6319 Vol 1. No. 2 Desember 2017

HAM, pembagian kekuasaan, eksistensi negara demokrasi dan negara hukum, serta hal-hal lain yang sesuai dengan perkembangan aspirasi dan kebutuhan bangsa. Perubahan UUD 1945 dilaksanakan dengan kesepakatan: ${ }^{7}$ tidak mengubah Pembukaan UUD 1945, mempertahankan bentuk Negara Kesatuan Republik Indonesia, mempertahankan sistem presidensiil (dalam pengertian sekaligus menyempurnakan agar betul-betul memenuhi ciri-ciri umum sistem presidensiil), memindahkan hal-hal normatif yang ada dalam Penjelasan UUD 1945 ke dalam pasal-pasal UUD 1945, dan menempuh cara adendum dalam melakukan amandemen terhadap UUD 1945.

Adanya bagian UUD 1945 yang dipertahankan dalam kesepakatan tersebut menunjukkan "kekuatan irasional-primordial yang muncul dalam bentuk kepercayaan" sehingga ada bagian dari UUD 1945 tetap dipertahankan hingga kini. Meskipun banyak kekurangannya dalam hukum in action, baik dilihat dari cara kerja pengadilan, pembuat undang-undang, maupun penegakan yang dilakukan oleh pemerintah dan aparatnya.

Setelah Presiden Soeharto turun maka "ia diganti oleh Wakil Presiden sampai habis waktunya"9. Wakil Presiden pada saat itu dijabat oleh B.J Habibie. B.J Habibie memimpin Indonesia tidak kurang dalam jangka waktu satu tahun karena pada tahun 1999 dilaksanakan pemilu. Hasil pemilu secara berturut-urut memberikan kedudukan

\footnotetext{
${ }^{7}$ Lima kesepakatan tersebut dilampirkan dalam Ketetapan MPR No. IX/MPR/1999 tentang Penugasan Badan Pekerja Majelis Permusyawaratan Rakyat Republik Indonesia untuk Melanjutkan Perubahan Undang-Undang Dasar Negara Republik Indonesia Tahun 1945. Lihat Jimly Asshiddiqie, "Ideologi, Pancasila, dan Konstitusi,hlm.8. jdih.ristek.go.id/?q=system/files/perundangan/9272 02140.pdf, Diakses 23 April 2009.

${ }^{8}$ Rahardjo, Op.Cit., hlm. 53.

${ }^{9}$ Pasal 8 UUD 1945 menjadi Pasal 8 Ayat (1) UUD 1945 pada Amandemen ke-3.
} 


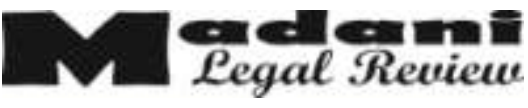

nomor satu di Indonesia kepada Gus Dur (1999-2001), Megawati (2001-2004), dan Susilo Bambang Yudhoyono (2004-2014).

Keberhasilan negara ditentukan oleh siapa yang menjadi pemimpin untuk mewujudkan tujuan negara. Tujuan negara Indonesia terdapat dalam pembukaan UUD 1945 yang tetap dipertahankan meskipun UUD 1945 diamandemen. Tujuan negara Indonesia yaitu melindungi segenap bangsa Indonesia dan seluruh tumpah darah Indonesia, memajukan kesejahteraan umum, mencerdaskan kehidupan bangsa, dan ikut melaksanakan ketertiban dunia.

"Hukum tidak lain hanyalah merupakan sarana bagi pemerintah atas tangan-tangan yang berkuasa untuk mengerahkan cara berfikir dan bertindak dalam rangka kebijakan tujuan nasional." 10 Allotts memandang "hukum sebagai sistem yang merupakan proses komunikasi. Oleh karena itu hukum menjadi subyek bagi persoalan yang sama dalam memindahkan dan menerima pesan seperti sistem komunikasi yang lain."11

Layaknya "tari topeng"12 atau lebih tepatnya "tari topeng multi karakter" 13 yang

10 http://www.bab5-warga_negara_dan_negara.pdf, Diakses pada tanggal 28 Desember 2009.

11 Otje Salman S dan Anton F. Susanto, Teori Hukum Mengingat, Mengumpulkan Dan Membuka Kembali, (Bandung: Refika Aditama, 2005) hlm. 96.

12 "Tari Topeng Topeng dan Kebudayaan, http://www.anneahira.con/tari-topeng.htm, Diakses 31 Oktober 2012 dan Wikipedia Bahasa Indonesia, Ensiklopedia Bebas Tari Topeng, http://id.wikipedia.org/wiki/Tari_Topeng, Diakses 31 Oktober 2012.

13 Kabari, October 1, 2012, Tari Topeng Multi Karakter, http://kabarinews.com/seni-tari-topengmulti-karakter/49755, Diakses 31 Oktober 2012. Topeng merupakan sarana untuk menunjukkan karakter yang berbeda dari sang penari. Arini Tathagati, Libur Lebaran Pertunjukan Bambu Petang Saung Angklung Udjo, Wisata Favorit Keluarga Saat Berlebaran, http://www.adirafacesofmdonesia.com/article.htm/1 426/-LiburLebaran-Pertunjukan-Bambu-PetangSaung-Angklung-Udjo--Wisata-Favorit-Keluarga-
Issn cetak 2597.9353 Issn online 2580.6319 Vol 1. No. 2 Desember 2017

sering dijadikan sindiran dari para seniman (diantaranya oleh seniman Didik Ninik Towok). Tari topeng multi karakter merupakan gambaran nyata yang senyatanyatanya atas keberagaman sifat dan watak manusia dalam kehidupan bermasyarakat. Topeng-topeng tersebut semakin nyata ketika kita mencermati "cita-cita reformasi" "14 yang didengungkan oleh aktivis, telah gagal dan melenceng jauh dari semangat awal untuk menciptakan Indonesia baru yang terbebas dari kepalsuan. "Semua hidup dalam kepalsuan, yakni kepalsuan hukum, kepalsuan birokrasi sehingga semua segi kehidupan berjalan dalam kepalsuan."15 Ditambah lagi dengan telah "turunnya kepercayaan terhadap institusi dan lembaga penyelenggara negara" ${ }^{\prime 16}$.

Terutama sekali kepercayaan publik terhadap kinerja pemerintah dalam pemberantasan korupsi di Indonesia terus merosot. "Per Desember 2011, kepercayaan publik menurun menjadi $44 \%$ dari bulan yang sama tahun sebelumnya yang $52 \%$ dan Desember 2008 yang pernah tercacat $77 \% .,{ }^{, 17}$ Olehnya itu masalah dalam tulisan ini adalah Kepalsuan hukum dalam penanganan Korupsi

Saat-Berlebaran, Diakses 31 Oktober 2012. Fandi Adhitya, 1:27 PM, Topeng Malang dari Dusun Glagandowo,http://wawasanfadhitya.blogspot.com/ 2012/02/topeng-malang-dari-dusun-

glagandowo.html, Diakses 31 Oktober 2012. Jenis topeng yang berasal dari Korea yang disebut dengan tal, biasanya dikenakan dalam pementasan tari topeng (talchum) yang memainkan berbagai karakter orang, hewan atau hantu. Saleum, 21-062012, Tal, http://beritakorea.com/917349, Diakses 31 Oktober 2012.

14 Zainuddin Ali, Filsafat Hukum, Sinar Grafika, Jakarta, 2011) hlm.101.

15 "Dedy Black Mundur dari DPRD Kota," http://harianrakyatbengkulu.com/dedy-blackmundur-dari-dprd-kota/, Diakses 17 Oktober 2012.

${ }^{16}$ Ian McWalters, Memerangi Korupsi Sebuah Peta Jalan Untuk Indonesia, (Surabaya: JPBooks, 2006), Halaman 149.

17 "PKS Sebut Kepalsuan, Pemberantasan Korupsi Runtuhkan Citra SBY, http://pksplajupalembang. blogspot.com/2012/01/pks-sebut-kepalsuanpemberantasan.html, Diakses 17 Oktober 2012. 
pada era Susilo Bambang Yudhoyono.

\section{METODE PENULISAN}

\section{Jenis Pendekatan}

Dalam penelitian ini penulis menggunakan jenis penelitian hukum normatif, yaitu suatu prosedur penelitian ilmiah untuk menemukan kebenaran berdasarkan logika keilmuan hukum dari sisi normatif. Terutama yang berkaitan dengan kepalsuan Hukum dalam penanganan Korupsi di era Susilo Bambang Yudhoyono.

\section{Jenis Data}

Jenis data yang digunakan adalah jenis data sekunder dimana data yang dihasilkan dari penelitian ini adalah data pustaka atau data sekunder. Untuk memperoleh data sekunder ini penulis melakukan penelusuran terhadap bahan hukum primer, sekunder dan tertier.

\section{Teknik Analisis data}

Setelah mendapatkan data yang terkait penelitian ini maka kemudian data akan dianalisis dengan beberapa cara untuk mendapatkan hasil penelitian yang kualitatif nantinya. Cara yang umum digunakan yaitu data diklasifikasikan kemudian data tersebut disistematisasikan lalu kemudian diinterpretasikan. Setelah proses tersebut dilalui, maka yang terakhir data tersebut akan kembali dievaluasi untuk mendukung penyelesaian suatu masalah dalam penelitian. ${ }^{18}$

\section{PEMBAHASAN}

\section{Kepalsuan hukum dalam penanganan Korupsi pada era Susilo Bambang Yudhoyono}

Turunnya kepercayaan publik terhadap kinerja pemerintah Susilo Bambang

18 Soejono Soekant. Pengenalan Penelitian Hukum, (Jakarta: Grafindo, , 2006) hlm. 225.
Yudhoyono (SBY) di bidang pemberantasan korupsi bukan tanpa alasan. Oleh karena "apa yang kita alami, dilihat dalam kenyataan sehari-hari, tetapi itu tidak bisa dianggap sebagai kenyataan sebenarnya (ultimate truth). Kenyataan yang sebenarnya adalah diam, tidak tampak (nothingess, formless)."19 "Apa yang dipermukaan tampak sebagai tertib, teratur, jelas, pasti, sebenarnya penuh dengan ketidakpastian." 20

Banyak kepalsuan dalam segala hal yang terus menurunkan kepercayaan masyarakat. "Musuh kita adalah kepalsuan, kepalsuan dalam segala hal. Menegakkan hukum tidak punya niat yang serius, menciptakan keamanan dan ketertiban tidak serius. Musuh kita adalah diri sendiri menjadi kinerja tidak bagus." 21 Hukum telah bergeser menjadi "permainan"22. "Di mana pun di dunia, hukum ditentukan oleh pemimpin politik untuk memperkuat posisinya". ${ }^{23}$

Betapa tidak, sejumlah besar kasus korupsi di Indonesia ternyata melibatkan kader partai besutan Presiden Susilo Bambang Yudhoyono. Selogan pemberantasan korupsi serta pemerintahan yang bersih hanyalah sekedar konsumsi janji-janji tipuan belaka. "Kini banyak kalangan menuding Partai Demokrat sebagai sarangnya para koruptor."24

"Dari skandal yang terungkap pada tahun 2011, tampaknya sebagian besar kasus mengarah pada kasus korupsi politik, terutama terkait dengan pendanaan partai politik

\footnotetext{
${ }^{19}$ Rahardjo, Op.Cit., hlm. 130.

${ }^{20}$ Sudjito, ,"Chaos Theory Of Law: Mimbar Hukum Vol. 18 No. 2 (Juni 2006) Dan Penjelasan atas Keteraturan dan Ketidakteraturan dalam Hukum", hlm. 162, http://isjd.pdii.lipi.go.id/admin/jumal/ 18206159175.pdf, Diakses 31 Oktober 2012.

${ }^{21} \mathrm{http}: / /$ pksplajupalembang.blogspot.com/2012/01/P ks-sebut-kepalsuan-pemberantasan.htinl, Op.Cit.

${ }^{22}$. Rahardjo, Op.Cit., hlm. 61.

${ }^{23}$ Ibid., hlm. 89-90.

${ }^{24}$ Menguak, Bungkus Kepalsuan Partai Penguasa" http://kabarnet.wordpress.com/2012/02/01/Mengua k-bungkus-kepalsuan-partai-penguasa/, Diakses 17
} Oktober 2012. 


\section{Regal Revieu}

diantaranya:"25

Dana bail out Bank Century diduga dipergunakan oleh Partai Demokrat dengan berbagai cara untuk membiayai kampanye dan strategi pemenangan dalam Pemilu 2009 lalu. Demikian juga kasus yang dilakukan oleh Nazarudin, bisa dikategorikan sebagai kasus korupsi politik karena dana hasil korupsi dipergunakan untuk membiayai keperluan partai. Dari sejumlah saksi yang diperiksa di Pengadilan Tindak Pidana Korupsi jelas terungkap bagaimana uang hasil korupsi dipergunakan untuk membiayai Kongres Partai Demokrat, termasuk membiayai pemenangan Anas Urbaningrum. Demikan juga suap di Kemenakertrans, ternyata juga melibatkan kepentingan politisi. Uang suap itu, oleh Dharnawati dari dimaksud untuk para pejabat di Kemenakertrans termasuk Menteri terkait proyek Percepatan Pembangunan Infrastruktur Daerah (PPID). Tetapi Muhaimin menyatakan namanya dicabut oleh orang yang menerima suap. Kebenarannya tentu masih perlu ditunggu di pengadilan. Akan tetapi kasus Kemenakertrans tidak bisa dilepaskan dari adanya kepentingan politik.

Polemik seputar status hukum sebanyak 61 kepala daerah yang terjerat kasus dugaan korupsi tersendat karena mayoritas dari jumlah itu adalah kader Partai Demokrat. Mereka mendapat "perlakuan khusus" dari partai penguasa. Para koruptor yang bukan kader Demokrat, ramai-ramai berpindah haluan ke Demokrat. Tujuannya bisa ditebak, suaka politik adalah yang utama.

Dalam kehidupan kita, entah berapa banyak kita memakai topeng untuk menutupi semua kepalsuan yang kita miliki. Semuanya rata dari level teratas hingga level terbawah, dari politisi yang sangat lihai mempermainkan kata-kata hingga ke orang biasa. Tentunya

25 J. Danang Widoyoko, Oligarki Dan Korupsi Politik Indonesia Strategi Memutus Oligarki Dan Reproduksi Korupsi Politik, (Malang: Setara Press, 2013) hlm. 91.
Issn cetak 2597.9353 Issn online 2580.6319 Vol 1. No. 2 Desember 2017

semuanya itu dalam bentuk yang lain. "Watak manusia Indonesia masih terbelenggu dengan mantera dan semboyan, seperti keadilan untuk semua, kemakmuran rakyat yang adil, hak-hak asasi manusia. Semuanya itu menunjukan bahwa manusia Indonesia memakai topeng di depan umum, menyembunyikan wajahnya yang sebenarnya, serba takut dan khawatir membuka wajahnya." 26

Lagu dengan judul "Topeng" yang dibawakan oleh group Peter Pan pun ikut popular dimasyarakat untuk memaksa pemerintah membongkar kepalsuan hukum. Berdasarkan topeng-topeng yang digunakan untuk menutup kepalsuan muncul pertanyaan bagaimanakah kepalsuan hukum dalam penanganan korupsi di Indonesia pada era pemerintahan Susilo Bambang Yudhoyono?

Mengingat "cara pandang seseorang tentang hukum akan ditentukan oleh cara orang tersebut merekonstruksi, menciptakan atau menafsirkan mengenai apa yang disebut hukum itu." 27 Oleh karena itu, penulis memandang perlu adanya persamaan persepsi dalam tulisan ini mengenai pengertian hukum dan pemerintah. Hukum dalam tulisan ini tidak terbatas pada hukum yang tertulis dalam peraturan perundang-undangan saja melainkan juga hukum tidak tertulis yang berupa perbuatan atau kebijakan pemerintah dalam menghadapi suatu kondisi. Demikian juga yang dimaksud dengan pemerintah dalam tulisan ini tidak terbatas pada "pemerintah dalam arti sempit"28 (Presiden) melainkan "pemerintah dalam arti luas" 29 (orang-orang yang diberikan kewenangan oleh peraturan yang ada) khususnya Presiden, DPR, Kepala Daerah, KPK, Kepolisian dan para Hakim.

\footnotetext{
${ }^{26}$ Desi Ariani,"'Buka Dulu Topeng Mu Hai Manusia Indonesia,http://politik.kompasiana.com/2010/10/1 6/buka-dulu-topeng-mu-hai-manusia-indonesia/, Diakses 31 Oktober 2012.

${ }^{27}$ Salman, Op.Cit., hlm. 3.

28 http://www.bab5-warga_negara_dan_negara.pdf, Op.Cit.. hlm. 113.

${ }^{29}$ Ibid., hlm.113.
} 


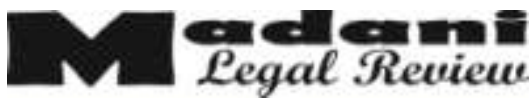

Mengingat bahwa telah terjadi "krisis yang menimpa sekalian bidang fundamental hukum, baik pembuat hukum, penegakan hukum maupun pengadilan." 30

"Makna atau pendefinisian tentang realitas tertentu akan sangat bergantung kepada siapa penafsir, untuk tujuan apa dia menafsirkan dan dalam kondisi bagaimana penafsiran dilakukan, serta banyak lagi lainnya." 31 Makna atau pendefinisian kondisi hukum Indonesia secara umum selalu dicerminkan dari aparat dan perangkat hukum yang ada meskipun secara sosiologis peran rakyatlah yang dibutuhkan untuk penegakkannya. Tetapi konsep feodalisme yang masih tertata rapi menyebabkan aparat dan perangkat hukum menjadi tolok ukur penegakannya.

Ternyata di sini rakyat telah salah membuat pilihan, "menjadikan aparat penegak hukum dan perangkatnya sebagai acuan dalam penegakan hukum. Akibatnya kepercayaan rakyat pada hukum secara keseluruhan menjadi runtuh"32. "Tanda-tanda ketidak percayaan dan kurang penghormatan masyarakat terhadap hukum"33 dimunculkan. Padahal "masalah idealism, 'moral dalam hukum, ${ }^{34}$, kepercayaan kepada hukum, dan sebagainya merupakan modal yang sangat penting dalam suatu negara berdasarkan hukum" ${ }^{\prime 35}$.

Menurut Sampford, "masyarakat sesungguhnya (realitasnya) selalu berada dalam kondisi/situasi keos atau pada jalinan hubungan-hubungan yang tidak dapat

${ }^{30}$ Rahardjo, Op.Cit., hlm. 199.

${ }^{31}$ Salman, Op.Cit., hlm. 8.

${ }^{32}$ Hans C. Tangkau, Pembuktian Terbalik Dalam Penanganan Tindak Pidana Korupsi, http://repo.unsrat.ac.id/107/1/PEMBUKTIANTERBALIK-DALAM-PENANGANAN-TfNDA K-PIDANA-KORUPSI.pdf, Diakses pada tanggal 17 Oktober 2012.

${ }^{33}$ Rahardjo, Op.Cit., hlm. 199.

${ }^{34}$ Bernard L. Tanya, dkk, Teori Hukum Strategi Tertib Manusia Lintas Ruang Dan Generasi, , (Yogyakarta: Genta 2013) hlm. 34

${ }^{35}$ Rahardjo, Op.Cit., hlm. 51.
Issn cetak 2597.9353 Issn online 2580.6319 Vol 1. No. 2 Desember 2017

diprediksi dan tidak sistematis"36. "Salah satu faktor yang mempengaruhi misalnya kekuatankekuatan (kekuasaan) dan saling tarik-menarik dan berbenturan di dalamnya." ${ }^{37}$ Para pengemban profesi hukum sangat mempengaruhi kondisi keos tersebut.

"Profesi hukum berkaitan dengan masalah mewujudkan dan memelihara ketertiban yang berkeadilan di dalam kehidupan bermasyarakat. Penghormatan terhadap martabat manusia merupakan titik tolak atau landasan bertumpunya atau tujuan akhir dari hukum."38 Masyarakat akan memandang para pengemban profesi hukum sebagai "orang yang mewujudkan pelayanan daripada orang yang mencari keuntungan bagi diri sendiri"39. Oleh karenanya, "dibutuhkan pengendalian diri secara individual bagi para pengemban profesi tersebut untuk tetap berpegang kuat pada nilai-nilai dan normsnorms yang menjiwai tugas para pengemban profesi" ${ }^{40}$.

Menurut Talcott Parsons "para pengemban profesi dalam mengemban profesinya memiliki tujuan pokok untuk mewujudkan hasil karya yang obyektif dan pengakuan atau rekognisi yang bisa berupa lambang atau uang"41. Uang dapat menjadi pengakuan nyata atas kualitas professional. Namun dengan uang dapat menimbulkan kenyataan yang menyimpang dari kondisi ideal yang mengarah kepada gejala komersialisme dan ketidakjujuran (korupsi).

Orang pada umumnya akan merasakan kepuasan jika berhasil menjalankan pola-pola prilaku yang dianggap benar (diterima) oleh masyarakat, sebaliknya merasa malu jika tidak berhasil (gagal) menjalankannya. "Mekanisme

\footnotetext{
${ }^{36}$ Salman, Op.Cit., hlm. 104.

${ }^{37}$ Ibid., hlm. 104-105.

${ }^{38}$ Lili Rasjidi dan Ira Thania Rasjidi, Dasar-Dasar Filsafat dan Teori Hukum, (Bandung: Aditya Bakti 2007) hlm. 92.

${ }^{39}$ Ibid., hlm. 90

${ }^{40}$ Ibid., hlm. 90.

${ }^{41}$ Ibid., hlm. 95
} 


\section{Regal Revitew}

perilaku yang mengintegrasikan kepuasan individu dan ekspektasi (harapan) kemasyarakatan akan berfungsi secara minus jika tejadi keselarasan antara karya obyektif dan landasan serta lambang-lambang rekognisi." ${ }^{42}$ Jika tidak maka menimbulkan rasa tidak aman dan konflik. Seorang yang berpegang teguh pada hasil karya obyektif yang seharusnya (mematuhi etika dan kode etik profesi) tidak akan mengorbankan hasil karya obyektif untuk memperoleh lambang-lambang rekognisi.

Marc Galanter menyatakan bahwa "profesi hukum lebih mementingkan fasilitas bisnis ketimbang berusaha untuk meringankan penderitaan manusia dan menolong orang" ${ }^{43}$. Hanya saja "praktik hukum yang berwajah jamak sudah mengglobal dan merambah hampir ke semua negara Eropa dan tidak ketinggalan negara-negara berkembang seperti Indonesia." 44

Mari kita lihat dari lembaga yang menentukan isi peraturan perundang-undangan (DPR). Mereka sebagian besar merupakan para politisi yang terpilih untuk duduk di DPR. "Mereka bersumpah atas nama Tuhan tidak terlibat korupsi. Ada yang pura-pura mendukung KPK tetapi justru menusuk dari depan dengan keinginan memangkas kewenangan KPK. Ada juga yang pura-pura ngotot dengan atas nama hukum tidak menyerahkan kasus korupsi ke KPK demi melindungi institusinya." ${ }^{45}$

Begitu juga dalam pemilihan kepala daerah, ada yang begitu perhatian turun ke jalan-jalan, ke pasar dan ke masyarakat kecil membagikan sumbangan sembako. Diiringi dengan janji-janji untuk memberantas kasus

\footnotetext{
42 Ibid.,

${ }^{43}$ Rahardjo, Op.Cit., hlm. 51-52.

${ }^{44}$ Ibid., hlm. 52.

45 Tom Artandi, 04 September 2012, Topeng Kepalsuan dalam Kehidupan Kita, http://sosbud.kompasiana.com/2012/09/04/topengkepatsuan-dalam-kehidupan-kita/, Diakses 17 Oktober 2012.
}

Issn cetak 2597.9353 $\mathbf{\|}$ |ssn online 2580-6319 Vol 1. No. 2 Desember 2017

korupsi yang mencuat di masyarakat. Tetapi ketika terpilih mereka dengan sengaja lupa untuk melaksanakan janji-janjinya itu. "Agenda pertama setelah jabatan diraih adalah memperkaya diri dan setor ke partainya meski dengan jalan korupsi." 46

Ini semua demi kekuasaan dan uang, tanpa memperdulikan kelayakannya untuk menjabat sebagai anggota DPR, Menteri, atau Kepala Daerah. Bila menguntungkan sebuah partai maka akan didukung dengan suara bulat. Kondisi ini juga menyebabkan terjadinya koalisi antar partai yang masing-masing berbeda di berbagai daerah. "Semakin banyak kader partai politik ditangkapi KPK, semakin anjlok elektabilitas partai politik tersebut" ${ }^{\text {"47 }}$. Demikian halnya yang terjadi pada Partai Demokrat yang menaungi SBY.

Tidak dapat dielakkan, akibat orangorang disekitarnya maupun kader dari partainya, citra Presiden SBY semakin turun karena dalam pemberantasan korupsi dan penegakan hukum penuh dengan kepalsuan. "Terjadi kepalsuan dalam penegakan hukum termasuk dalam menciptakan keamanan dan ketertiban." 48

Pemerintah harus jujur dalam penegakan hukum dan tidak perlu ada pemalsuan. Jika hal tersebut tidak disikapi dengan tegas maka kedepannya akan sangat membahayakan kehidupan berbangsa dan bernegara. "Untuk melaksanakan perubahan fundamental ini

${ }^{46}$ Komaruddin Hidayat, Senin, 13 Agustus 2012, Mengakhiri Mitos Bangsa yang Kalah, http://www.metrotvnews.com/metromain/analisdeta il/2012/08/13/280/Mengakhiri-Mitos-BangsayangKalah, Diakses 1 Oktober 2012.

47 Nikky Sirait, Minggu, 8 Juli 2012, Awas, Dibandingkan Demokrat, Nasib Golkar BisaLebih Terpuruk, http://jaringnews.com/politikperistiwa/umum/18368/awas-dibandingkandemokrat-nasib-golkar-bisa-lebihterpuruk, Diakses 1 Oktober 2012.

${ }^{48}$ Achsin, Monday, 09 January 2012 14:07, PKS: SBY Penuh Kepalsuan dalam Pemberantasan Korupsi, http://www.itoday.co.id/politik/pks-sbypenuh-kepalsuan-dalam-pemberantasan-korupsi, Diakses 17 Oktober 2012. 


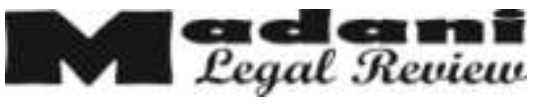

harus disikapi dengan sikap tegas dan berdiri pada garda terdepan arus besar perubahan dalam restorasi Indonesia bersama dengan rakyat untuk mencapai Indonesia baru."

Pada saat ini ternyata "untuk bersikap jujur dengan mengungkap ketidakjujuran kolektif, malah dipenjarakan, dituduh, atau dicari-cari kesalahan masa lalunya untuk menunjukkan bahwa pelaku memiliki 'sejarah' ketidakkejujuran"50. Seperti yang dialami Susno Duaji dan Agus Condro, yang membongkar korupsi disekitarnya, malah diadili sebagai orang yang bersalah. Agaknya, masyarakat melihat, bahwa para pejabat publik dan penegak hukum, tidak segan-segan menyingkirkan siapa saja yang menghalanginya.

Kemerosotan "moralitas" 51 pun terjadi terhadap nilai kejujuran dan penghargaan atas nilai kebenaran yang menimbulkan sikap permisif masyarakat kita terhadap koruptor. Kita tahu, korupsi adalah perbuatan jahat, tetapi masyarakat kita masih memperlakukan begitu sangat baik terhadap koruptor. Seolah mencuri uang negara, yang tak lain adalah mengambil hak warga negara lainnya dianggap biasa dan lumrah. Maka, menghormati koruptor dianggap hal biasa. "Masyaratkat kita sudah dibiasakan dengan nilai-nilai palsu dan berbudi palsu. Kalau ada orang yang mencoba membuka kepalsuan, dianggap 'tidak bersih' lingkungan." 52

Kejanggalan muncul ketika para wakil rakyat membandingkan sistem hukum dengan jalan-jalan ke negara lain yang pada setiap

49 http://harianrakyatbengkulu.com/dedy-blackmundur-dari-dprd-kota/, Op.Cit.

50 Ons Untoro, 20 Jun 2011 11:25:00, Sebutir Kejujuran Ditengah Kepalsuan, http://www.tembi.net/id/news/beritabudaya/sebutirkejujuran-ditengah-kepalsuan-1506.html, Diakses pada tanggal 17 Oktober 2012.

51 W. Poespoprodjo L, Filsafat Moral Kesusilaan dalam Teori dan Praktek, (Bandung: Remadja Karya 1988) hlm.102.

${ }^{52}$ Untoro, Op.Cit.
Issn cetak 2597.9353 Issn online 2580.6319 Vol 1. No. 2 Desember 2017

hasil kunjungan tersebut belum pernah ada pembahasan yang jelas (sampai kepada publik), sudah mengatakan belum tentu bisa diadopsi (dapat hasil). "Lantas, kenapa perlu ada kunjungan kerja yang nota bene menghabiskan uang rakyat (apakah ini tidak masuk kategori korupsi)., ${ }^{, 53}$ Kemudian atas dasar ketidakjelasan tersebut muncullah ide "merevisi UU KPK" "54. Tujuannya hanya satu: "melemahkan fungsi dan wewenang KPK", agar tidak lagi menjadi super body seperti sekarang.

Seyogyanya KPK yang berdasarkan peraturan perundang-undangan pemberantasan korupsi, harus mempunyai prioritas sebagai lembaga yang independen dan mandiri untuk melaksanakan tugas dan kewenangannya, sekarang telah dipreteli. Wewenang KPK untuk melakukan penindakan, penyadapan, dan pencegahan sebagai mana yang telah diamanatkan UU Nomor 32 Tahun 2002 nampaknya telah menjadi momok menakutkan. Tidak saja bagi para koruptor, tapi juga bagi mereka yang berniat melakukan, berniat melindungi dan menyenangi korupsi itu sendiri. Bahkan KPK belum selesai menjalankan kewenangannya. Belum memiliki bukti yang kuat untuk meningkatkan dari penyelidikan ke tingkat penyidikan. "DPR kemudian menjadi 'pahlawan

\footnotetext{
${ }^{53}$ Woro Sembodhro, Rabu, "Maaf Rakyat Sudah Muak Dengan Kepalsuan ", http://surat-pembacajurnalismewarga.pelitaonline.com/news/2012/09/12 /maafrakyat-sudah-muak

dengankepalsuan\#.UH4TBdluWiY, Diakses 17 Oktober 2012.

54 Keberhasilan KPK membongkar banyak kasus korupsi menimbulkan banyak resistensi. Salah satu perlawanan dari koruptor adalah mengajukan judicial reviw terhadap UU KPK. Salah satu judicial reviw yang dikabulkan oleh Mahkamah Konstitusi adalah memisahkan aturan soal pengadilan tindak pidana korupsi dari UU KPK. J. Danang Widoyoko, Op.Cit., hlm. 138.

55 Layak DPR Menjadi Musuh Seluruh Rakyat?, http://www.voa-islam.com/news/osini/2012/ 09/27/20889/layak-dpr-menjadi-musuh-seluruhrakyat/, Diakses pada tanggal 1 Oktober 2012
} 


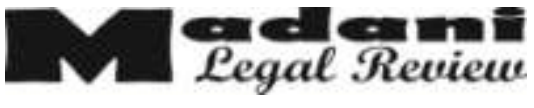

kesiangan'. Seolah tidak percaya dengan kinerja KPK. DPR gegabah membentuk Panitia Kerja (Panja) Hambalang." "S6 "Sebagai pejabat publik seharusnya, hati-hati dalam mengeluarkan setiap pernyataan, tulisan atau pendapat. Pernyataan yang tidak tepat akan menjadikan kontra produktif terhadap upaya pemberantasan korupsi. ${ }^{, 57}$

KPK "tidak dapat bekerja dengan tenang, jika hukum yang mereka gunakan banyak mengandung ketidak-pastian" ${ }^{\text {" }}$. Diantaranya terkait dengan Pasal 8 ayat (2) UU No. 30 Tahun 2002, KPK "berwenang mengambil alih penyidikan atau penuntutan terhadap pelaku tindak pidana korupsi yang sedang dilakukan oleh kepolisian atau kejaksaan". Ketentuan ini penyebab konflik antara KPK dan Polri.

Berlanjut dengan kasus korupsi simulator SIM di Korps Lalu Lintas RI. "Kepolisian Negara RI mengajukan gugatan praperadilan terhadap KPK yang menggeledah gedung Korps Lalu Lintas (Korlantas) Polri di Jakarta pada Selasa 31 Juli 2012. Kepolisian Negara RI menuntut ganti rugi material sebesar Rp.425 miliar dan nonmaterial Rp. 6 miliar, karena KPK dianggap telah melakukan pelanggaran dalam proses penggeledahan." 59

\footnotetext{
56 Masyithah Utrujjab Dwi N," Post-Kriminalitas KorupsiHambalang,http://www.negarahukum.com/ hukum/post-kriminalitas-korupsi-hambalang.html, Diakses 17 Oktober 2012.

57 Santi Pujirahayu, Jumat, "Mendukung Pemberantasan Korupsi" http://surat-pembacajumalismewarga.pelitaonline.com/news/2012/09/07 /mendukungpemberantasan

korupsi\#.UH4Up9luWiY, Diakses 17 Oktober 2012.

${ }^{58}$ Rahardjo, Op.Cit., hlm. 79.

59 Risnawati, Tuesday, October 30, 2012 - 09:44, Menko Polhukam: Gugatan Polri ke KPK Bukan Bentuk Perlawanan, http:// indonesiarayanews.com/ news/hukum-kriminal/ I 0-30-2012-09- 44/ menko-pothukam-gugatan-potrike-kpk-bukan-bentuk-perlawanan, Diakses 31 Oktober 2012. Arientha Primanita/Ratna Nuraini, "Gugatan Polisi Dilayangkan Sebelum Presiden Pidato" http://www.beritasatu.com/nasional/80287-
}

Issn cetak 2597.9353 Issn online 2580.6319 Vol 1. No. 2 Desember 2017

Kemudian pada Jumat malam 5 Oktober 2012, Kepolisian mengepung KPK. Atas kejadian ini mahasiswa menganggap sebagai titik klimaks dari ketidakmampuan SBYBoediono dalam mengatur pemerintahannya. Mahasiswa geram dan pada Rabu 10 Oktober 2012 mahasiswa menyampaikan aspirasinya di depan Gedung KPK menuntut supaya: ${ }^{60}$

Pertama, Perkuat kewenangan KPK untuk melakukan pemberantasan korupsi di negeri ini. Kedua, Copot Kapolri Jenderal Timur Pradopo, karena tidak dapat mengendalikan bawahannya. Ketiga, Menuntut mundur Pemerintahan SBY-Boediono dan keempat, Cabut mandat DPR-MPR.

Setelah pidato Presiden Susilo Bambang Yudhoyono untuk menengahi kemelut KPK dan Kepolisian Negara RI maka "Komisi Kepolisian Nasional (Kompolnas) mendesak Korps Lalu Lintas (Korlantas) Mabes Polri segera mencabut gugatan terhadap KPK. Kompolnas menganggap gugatan itu bisa memperburuk citra Polri yang semakin terpuruk dan sangat tidak logis sesama komponen penegak hukum saling gugat perdata. ${ }^{, 61}$

Dukungan terhadap KPK terus mengalir untuk mempertahankan keberadaan KPK. Bahkan rakyat bersatu padu untuk mengumpulkan dana yang dilakukan bagi pembangunan gedung KPK yang dikenal dengan aksi "sawer". Aksi ini memiliki arti sangat penting. "Maknanya ialah betapa rakyat sudah sangat muak dengan korupsi dan akan mendukung apa pun bentuk tindakan

gugatan-polisi-dilayangkan-sebelum-Presidenpidato.htini, Diakses 31 Oktober 2012.

${ }^{60}$ Oki Baren, Tuntutan Turunkan SBYBoediono Disuarakan di KPK, http://www.aktual.co/hukum/180546tuntutanturunkan-sby-boediono-disuarakan-di-kpk, Diakses 31 Oktober 2012.

61 Yudho Winarto, Selasa, 30 "Kompolnas desak Korlantas cabut gugatan ke KPK”, http://nasional.kontan.co.id/news/kompotnas-desakkorlantas-cabut-gugatan-kekpk/2012/10/30,

Diakses 31 Oktober 2012. 


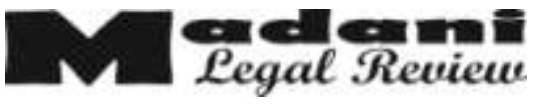

untuk melawan tindakan korup." ${ }^{, 62}$ Bagi rakyat KPK bukan baja sekadar institusi pemberantas korupsi atau sebuah komisi, melainkan "sebuah entitas yang akan terus menanamkan jiwa dan perilaku antikorupsi di negeri ini. KPK merupakan cermin dari semangat untuk memberantas korupsi hingga akar-akarnya" ${ }^{\text {"63 }}$ atau dengan "radikalisme"

"Di Indonesia, kita juga banyak menghadapi kekecewaan karena perkara korupsi dilarikan ke masalah administrasi, kekeliruan prosedur dan sebagainya." ${ }^{\text {,65 }}$ "Penjahat yang diketahui dan dipublikasikan dalam iringan-iringan media hanya penjahat palsu (pseudo-intellectual dader)." ${ }^{, 66}$ Oleh karena kepalsuan, citra yang dimainkannya, seperti tersangka palsu, terdakwa palsu, terpidana palsu, bukti palsu melalui simulasi pengadilan, fatamorgana hukum, imagologi hukum. Keduanya dikendalikan oleh tiang kekuasan sebagai penyangga terciptanya negara yang diimpikan akan mengabdi pada rakyatnya. Kekuasan tersebut bersatu dengan kejahatan dan sebagai tempat persembunyian yang sempurna agar leluasa bergerak dibalik topeng-topeng kekuasaan.

"Pengadilan saat ini bukan lagi merupakan rumah keadilan, melainkan (juga) untuk menerapkan undang-undang. Terjadilah 'persidangan undang-undang dan prosedur' dan bukan 'persidangan keadilan', sehingga orangpun bicara mengenai trials without justice." 67

Sangat disayangkan "pada saat masyarakat meyakini, bahwa sesorang melakukan korupsi, akhirnya harus menerima kenyataan lolosnya orang tersebut dari jaringan

\footnotetext{
${ }^{62}$ Benny Susetyo, "Media Indonesia, Makna Aksi Sawer untuk KPK", http://www.lazuardibirru.org/berita/kolom/maknaaksi-sawer-untuk-kpk/, Diakses 17 Oktober 2012. 63 Ibid.

${ }^{64}$ Rahardjo, Op.Cit., hlm. 66.

${ }^{65}$ Rahardjo, Op.Cit., hlm. 17.

${ }^{66}$ Dwi N, Op.Cit.

${ }^{67}$ Rahardjo, Op.Cit., hlm. 14.
}

\section{Issn cetak 2597.9353 I Issn online $2580-6319$ Vol 1. No. 2 Desember 2017}

hukum. Hukum dan pengadilan mendapat julukan baru sebagai 'pelabuhan yang aman' bagi para koruptor." 68

Jaksa Agung Muda Tindak Pidana Khusus (Jampidsus) Andi Irwanto prihatin dengan banyaknya perkara kasus korupsi yang diputus bebas oleh pengadilan di daerah diantaranya: ${ }^{69}$

"kasus yang melibatkan 34 bekas Anggota DPRD Kutai Kertanegara Kalimantan Timur semua diputus lepas dari segala tuntutan hukum, di Lampung Timur juga diputus bebas padahal jelas-jelas anggaran Pemda dititipkan ke BPR, yang mungkin itu juga tidak jelas kantornya. Begitu juga dengan kasus Pemkab Batubara, dimana Rp80 Millar dana APED di simpan di Bank Mega, Cikarang."

Sorotan tajam ditujukan pada prilaku hakim-hakim di Provinsi Jambi terutama terkait putusan perkara korupsi. Sebab dalam enam tahun terakhir banyak terdakwa kasus korupsi dan para pejabat yang terlibat kasuskasus besar yang diputus bebas oleh hakim pengadilan negeri (PN) di tingkat kasasi, sebagian besar putusan tersebut dimentahkan Mahkamah Agung (MA).

Menurut catatan Jambi Independent, vonis bebas dari hakim PN Jambi yang dimentahkan MA diantaranya terhadap terdakwa: ${ }^{70}$

"Syamawi Darahim, Kadis Budpar tahun 2005 yang terlibat kasus tindak pidana korupsi pembangunan proyek Taman Rekreasi Water Boom Jambi, senilai Rp 5,8 miliar tahun 2006 lalu. As'ad Syam, mantan Bupati Muarojambi. Terdakwa

${ }^{68}$ Ibid., hlm. 15.

69 Boy/jpn, "Prihatin Perkara Korupsi Diputus Bebas"http://www.radarbangka.co.idiberita/detail/g lobal/5518/prihatin-perkara-korupsi-diputusbebas.html, Diakses 31 Oktober 2012.

70 Mui/Ira, "Sebagian Koruptor yang Diputus Bebas, Kena di Tingkat Kasasi” http://www.jambiindependent.co.id/j io/index.php?option--com content\&view--article\&id $=17081,31$ Oktober 2012. 


\section{Regal Revicu}

kasus korupsi proyek pembangunan PLTD Unit 22 Sungai Bahar yang putusan kasasinya dijatuhkan ketika As'ad menjabat sebagai anggota DPR RI Dapil Jambi. Yang teranyar adalah kasus korupsi pemotongan dana pelatda PON dan bonus atlet senilai $\mathrm{Rp} 2,5$ miliar pada tahun 2008, dengan terdakwa Nasrun R Arbain (Mantan Ketua KONI Jambi)”.

Dapat dikatakan bahwa Indonesia mengalami "hyperreality"11. "Realitas telah tersingkir dan tereduksi dari posisinya.,"72 "Hukum mucul dalam bentuk keputusan yang ditandai keserakahan, dan muslihat birokrasi, turbulensi dan noise." ${ }^{, 3}$ Hukum pada posisi demikian tidak memiliki kekuasaan untuk menata dirinya, hukum berada pada titik keberantakan. Menurut Satjipto Rahardjo: ${ }^{74}$

"Kondisi keberantakan itu diperlihatkan oleh kondisi hyperregulated yaitu tumpang tindih (benturan) aturan karena terlalu banyak aturan, proses pembodohan masyarakat, penindasan, sampai kepada miskinnya kreativitas dan matinya nurani penegak hukum. Akibatnya muncul apa yang digambarkan sebagai model penyelesaian masalah di luar hukum formal, tanpa harus menunggu prosedur yang cenderung lama dan berbelit-belit, masa mengadili pelaku pada saat itu di tempat kejadian, mulai dari peradilan massa sampai kepada cap (stigma) tertentu terhadap birokrat. Situasi demikian muncul karena sudah tidak ada lagi kepercayaan yang bias dilimpahkan kepada lembaga penyokong keadilan. Keadilan menjadi sangat eksklusif dan hanya dimiliki oleh segelintir kelompok yang memiliki kemampuan mengalokasikan sumber-sumber kekuasaan. Situasi itu telah memicu dan mendorong masyarakat yang termarjinalkan untuk bergerak. Semakin kuatnya tuntutan masyarakat demikian itu,

\footnotetext{
71 Salman S. dan Anton F. Susanto, Op.Cit., hlm. 136.

${ }^{72}$ Ibid., hlm. 137.

${ }^{73}$ Ibid., hlm. 137.

${ }^{74}$ Ibid., hlm. 149-150.
}

Issn cetak 2597.9353 Issn online $2580-6319$ Vol 1. No. 2 Desember 2017

maka dimulailah 'era hukum rakyat' rakyat mulai menguasai jalan dan mengambil alih penafsiran, "siapa menguasai jalan dia menguasai dunia”.

Untuk mengatasi dan memperlunak kerusakan budaya dan lingkungan setempat, yang perlu dilakukan "penafisran kembali" Arti penafsiran kembali di sini mempunyai makna budaya dan bukan suatu usaha subversi terhadap hukum yang berlaku ${ }^{75}$ terhadap hukum yang harus diterapkan dalam usaha penegakan hukum itu. Romli Atmasasmita mengatakan bahwa ${ }^{76}$ :

"dalam tubuh aparat penegak hukum (law enfocement officer) dewasa ini muncul sikap anomistik (sosial anomie) dalam menghadapi penegakan hukum, terutama terhadap kasus kolusi, korupsi dan nepotisme (KKN). Sikap ini muncul, karena telah terjadi inkonsistensi dalam praktek yang dipicu oleh penafsiran yang berbeda-beda antara hakim, jaksa, polisi bahkan oleh penasehat hukumnya. Perbedan penafsiran tersebut bisa disebabkan oleh adanya kepentingan yang berbeda-beda, sehingga usaha kearah the real law enfocement masih menjadi mitos".

Kita tidak dapat menilai keefektivan hukum yang mengatur penanganan korupsi. Pengukuran keefektivan hukum memiliki kelemahan. Menurut Allotts, "kelemahan dalam mengukur keefektivan hukum, dapat terlihat dalam kurangnya pengawasan dan pelaksanaan norma-norma yang disebabkan tidak adanya umpan balik yang cukup dalam sistem undang-undang yang sah",77. Meskipun di Indonesia telah dibentuk sistem, atau lembaga pengawas interen serta eksteren yang khusus untuk memberantas korupsi.

\footnotetext{
75 . Rahardjo, Op.Cit., hlm. 103.

${ }^{76}$ Binoto Nadapdap, , Korupsi Belum Ada Matinya, (Jakarta: Permata Aksara, 2014) hlm. 75.

77 Salman S. dan Anton F. Susanto, Op.Cit., hlm. 97.
} 


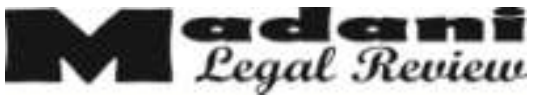

Selain itu "hukum tidak akan bekerja dengan baik jika tidak sesuai dengan konteks

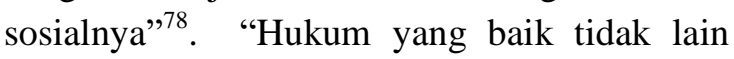
adalah hukum yang mencerminkan nilai-nilai yang hidup dalam masyarakat.,79 Cara berhukum suatu bangsa pun mempengaruhi hukum yang baik karena "cara berhukum suatu bangsa tidak bisa dipisahkan dari cara bangsa itu bermasyarakat secara khas" atas hukum atau perundang-undangan yang lebih penting lagi adalah perilaku manusia yang memiliki komitmen terhadap kesusahan orang banyak, terutama rakyat kecil”"81. Untuk itu "hukum harus menyerap dan mendapat pencerahan dari ilmu-ilmu sosial (the isolation of legal order) ${ }^{\prime 82}$.

Menurut Francis Fukuyama "dengan social capital yang di dalamnya sarat dengan nilai-nilai kebersamaan, tolong-menolong, saling percaya dan kejujuran, menjadi komponen yang sangat signifikan pengaruhnya terhadap efektivitas penggunaan chaos theory of law" ${ }^{\prime 3}$. Segalanya harus dimulai dari diri sendiri (ibda bi nafsihi) bukan dengan mengharap pada pihak lain. Sikap egois, antroposentris, harus dikemas sedemikian rupa agar menyatu dengan sikap sosial dan sikap rendah hati (tawadhu) sebagai kalifatullah. Menurut Allotts diperlukan "penyesuaian hukum untuk merubah kondisi-kondisi sosial yang merupakan bagian kerjanya melalui penegasan kembali batasan-batasan instrument yang sah" ${ }^{, 4}$.

Kondisi keos yang ditimbulkan oleh kepalsuan hukum dalam penanganan korupsi di Indonesia pada era pemerintahan Susilo Bambang Yudhoyono, bukanlah sesuatu yang harus ditakuti atau dihindari atau dilawan

\footnotetext{
${ }^{78}$ Ibid.,, hlm. 97.

${ }^{79}$ Rasjidi,dan Ira Thania Rasjidi, loc.cit.

${ }^{80}$ Rahardjo, Op.Cit., hlm. 72.

${ }^{81}$ Rahardjo , Op.Cit., hlm. 19.

${ }^{82}$ Rahardjo, Op.Cit., hlm. 135.

${ }^{83}$ Sudjito, Op.Cit., hlm. 167.

${ }^{84}$ Salman S. dan Anton F. Susanto, Op.Cit., hlm. 97.
}

Issn cetak 2597.9353 Issn online 2580.6319 Vol 1. No. 2 Desember 2017

dengan antipati. Tetapi di dalamnya terdapat kemungkinan atau peluang yang "pada dasarnya pandangan umum tentang hukum akan berubah total sebagai sebuah lonjakan paradigmatik seperti yang tejadi dalam ilmu pengetahuan lainnya" ${ }^{\circ 5}$. Oleh karena itu langkah yang paling pertama dan utama untuk membangun kepercayaan masyarakat adalah dengan melakukan "perubahan paradigma hukum dari paradigma formal ke paradigma substansial" ${ }^{166}$.

Paradigma substansi lebih mengutamakan substansi hukumnya. Substansi hukum lebih utama jika ditentukan oleh warga masyarakat sendiri. "Mereka itulah yang secara detail paham apa yang terbaik dan bias dilakukan oleh masyarakat, agar hukum itu berlaku secara teologis, fisiologis dan sosiologis, bukan sekedar berlaku formal." ${ }^{\text {87 }}$

Kekacauan atau ketidakpatuhan memang hadir ketika seseorang mengambil pandangan reduksionistik dan memusatkan perhatian pada perilaku yang menyimpang saja. Menurut Prigogine dan Stengers "ketidakpatuhan atau kekacauan tidak akan terus bertahan pada kedudukannya seperti itu, melainkan berubah atau berkembang menjadi ketertiban (order out of chaos)" ${ }^{\text {\$8 }}$. Kekacauan berkembang menjadi ketertiban jika menggunakan dan memandang kekacauan tersebut dengan "sikap holistik pada perilaku keseluruhan sistem secara terpadu" 89 . "Dari ketertiban ke kekacauan dan kembali ke ketertiban"90. Oleh karenanya "ketidakpatuhan kepada hukum perlu didengar dan diterima sebagai usaha untuk mengkoreksi adanya sesuatu yang tidak benar" ${ }^{\prime 91}$.

Satjipto Rahardjo menyatakan bahwa "sepanjang sejarah, manusia membangun dan

\footnotetext{
${ }^{85}$ Ibid., hlm. 106.

${ }^{86}$ Rahardjo, Op.Cit., hlm.53.

${ }^{87}$ Sudjito, Op.Cit., hlm.172.

${ }^{88}$ Rahardjo, Op.Cit., hlm. 125.

${ }^{89}$ Sudjito, Op.Cit., hlm. 164.

${ }^{90}$ Rahardjo, Op.Cit., hlm. 27.

${ }^{91}$ Rahardjo Op.Cit., hlm. 9.
} 


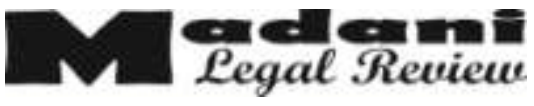

mematuhi hukum (making the law) dan merobohkan hukum (breaking the law)",92. Indonesia perlu belajar ke Jepang karena menurut Satjipto "Jepang telah menempatkan suatu posisi awal yang hampir sama dengan Indonesia, yaitu menerima penggunaan hukum modem sebagai suatu institusi yang dipaksakan dari luar. Jepang juga mengalami pertemuan antara dua yang berbeda yakni kultur Jepang dan Barat"93. Contohnya: "tata tertib Jepang yang tidak didasarkan pada akal-pikiran, tetapi pada hatinya" $"$.

Untuk itu "diperlukan adanya keberanian dari para pembuat putusanputusan hukum untuk menciptakan prosedur luar biasa (extra-ordinary measures) dan membangun kultur kebersamaan (corporate cultur) dalam proses peradilan"95. Mengingat "hukum tidak dapat dipisahkan dengan kekuasaan"96 maka diperlukan kekuasaan dengan watak-watak yang baik. Menurut Satjipto kekuasaan tersebut minimal memenuhi kriteria-kriteria seperti: ${ }^{97}$

Pertama, Kekuasaan harus berwatak mengabdi kepada kepentingan umum. Kedua, Kekuasaan harus melihat kepada lapisan masyarakat yang susah. Ketiga, Kekuasaan harus selalu memikirkan kepentingan public. keempat, Kekuasaan hares kosong dari kepentingan subyektif dan terakhir Kekuasaan harus bersifat mengasihi.

Meskipun hukum itu tidak sempurna, akan tetapi jikalau semangat para penyelenggara pemerintahan baik, maka hukum itu tidak akan merintangi jalannya negara. "Dan apapun yang dilakukan dalam hukum, tak boleh sekali-kali mengabaikan aspek manusia sebagai bagian yang sentral dari hukum itu, karena hukum dibuat untuk

\footnotetext{
92 Ibid., hlm.1.

${ }^{93}$ Rahardjo, Op.Cit., hlm. 87.

${ }^{94}$ Rahardjo, Op.Cit., hlm. 19.

${ }^{95}$ Rahardjo, Op.Cit., hlm. 5.

96 Munir Fuadi, , Filsafat dan Teori Hukum Postmodern, (Bandung: Citra Aditya Bakti, 2005) hlm. 161.

${ }^{97}$ Rahardjo, Op.Cit., hlm.54.
}

\section{Issn cetak 2597.9353 I Issn online $2580-6319$ Vol 1. No. 2 Desember 2017}

manusia bukan sebaliknya." $" 98$ Tidak kalah pentingnya dari uraian di atas bahwa sifat dasar manusia harus selaras dengan manusia lain sebagai perwujudan hukum alam atau hukum Tuhan. Seperti yang dinyatakan oleh Agustinus, bahwa "prinsip jangan berbuat kepada orang lain, apa yang engkau tidak ingin berbuat" "99 yang menampakkan rasa keadilan harus dilaksanakan. Semoga saja "kebenaran muncul dari perbedaan dan benturan pendapat (les chocs des opinions) atau konflik"100.

\section{KESIMPULAN}

Berdasarkan gambaran diatas terjadi kondisi keos disebabkan terjadinya kepalsuan Hukum dalam penanganan korupsi di Indonesia

\section{DAFTAR PUSTAKA}

Anshori, Abdul Ghofur. Filsafat Hukum Sejarah, Aliran dan Pemaknaan. Yogyakarta: Gadjah Mada University Press, 2006.

Ali, Zainuddin. Filsafat Hukum. Jakarta: Sinar Grafika, 2011.

Fuadi, Munir. Filsafat dan Teori Hukum Postmodern. Bandung: Citra Aditya Bakti, 2005.

L. Tanya, Bernard, dkk. Teori Hukum Strategi Tertib Manusia Lintas Ruang Dan Generasi. Yogyakarta: Genta, 2013.

McWalters, Ian. Memerangi Korupsi Sebuah Peta Jalan Untuk Indonesia. Surabaya: JPBooks, 2006.

Nadapdap, Binoto. Korupsi Belum Ada Matinya. Jakarta: Permata Aksara, 2014.

Poespoprodjo L, W. Filsafat Moral Kesusilaan dalam Teori dan Praktek. Bandung: Remadja Karya, 1988.

Rahardjo, Satjipto. Sisi-Sisi Lain dari Hukum di Indonesia. Jakarta: Kompas, 2006.

Rasjidi, Lili dan Ira Thania Rasjidi. Dasar-

\footnotetext{
98 Ibid., hlm. 5-6.

99 Abdul Ghofur Anshori, Filsafat Hukum Sejarah, Aliran dan Pemaknaan, (Yogyakarta, Gadjah Mada University Press, 2006) hlm. 16.

${ }^{100}$ Rahardjo, Op.Cit., hlm. 151.
} 
Dasar Filsafat dan Teori Hukum. Bandung: Aditya Bakti, 2007.

Salman S, Otje dan Anton F. Susanto. Teori Hukum Mengingat, Mengumpulkan Dan Membuka Kembali. Bandung: Refika Aditama, 2005.

Soekanto, Soejono. Pengenalan Penelitian Hukum. Jakarta: Grafindo, 2006.

Widoyoko, J. Danang. Oligarki Dan Korupsi Politik Indonesia Strategi Memutus Oligarki Dan Reproduksi Korupsi Politik. Malang: Setara Press, 2013.

Mengalir Catatan Kritis tentang Pergulatan Manusia dan Hukum, Jakarta: Kompas, 2008.

Achsin, "PKS: SBY Penuh Kepalsuan dalam Pemberantasan Korupsi", http://www.itoday.co.id/politik/pks -sby-penuhkepalsuan-dalampemberantasan-korupsi, Diakses 17 Oktober 2012.

Primanita, Arientha dan Ratna Nuraini, Gugatan Polisi Dilayangkan Sebelum Presiden Pidato, http://www.beritasatu.com/nasional /80287-gugatan-polisi-dilayangkansebelum-presiden-pidato.html, Diakses Oktober 2012.

Susetyo, Benny, "Media Indonesia, Makna Aksi Sawer untuk KPK", http://www.lazuardibirru.org/berita/ kolom/makna-aksi-sawer-untukkpk/, Diakses 17 Oktober 2012.

Boy/jpn, "Prihatin Perkara Korupsi Diputus Bebas," http://www.radarbangka.co.id/berit a/detail/global/5518/prihatinperkara-korupsi-diputusbebas.htmi, Diakses 31 Oktober 2012.

Ariani, Desi, "Buka Dulu Topeng Mu Hai Manusia Indonesia" http://politik.kompasiana.com/2010 /10/16/buka-dulu-topengmu-haimanusia-indonesia/, Diakses pada 31 Oktober 2012.
Issn cetak 2597.9353 Issn online 2580.6319 Vol 1. No. 2 Desember 2017

Adhitya, Fandi,"Topeng Malang dari Dusun Glagandowo, http://wawasanfadhitya.blogspot.co $\mathrm{m} / 2012 / 02 /$ topeng-malang-daridusunglagandowo.html, Diakses 31 Oktober 2012.

Tangkau, Hans C."Pembuktian Terbalik Dalam Penanganan Tindak Pidana Korupsi'http://repo.unsrat.ac.id/10 7/1/PEMBUKTIAN-TERBALIKDALAM-PENA NGANAN TINDAK - PIDANA KORUPSI.pdf, Diakses 17 Oktober 2012.

Asshiddiqie, Jimly, "Ideologi, Pancasila, dan Konstitusi," http://www.jdih.ristek.go.id/?q=sys tem/files/perundangan/927202140. pdf, Diakses 23 April 2009.

Asshiddiqi, Jimly, dkk, 2006, Gagasan amandemen UUD 1945 dan Pemilihan Presiden Secara Langsung, Setjen \& Kepaniteraan MKRI, Jakarta.

Hidayat, Komaruddin, "Mengakhiri Mitos Bangsa yang Kalah", http://www.metrotvnews.com/metr omain/analisdetail/2012/08/13/280/ Mengakhiri-Mitos-Bangsa yangKalah, Diakses 1 Oktober 2012.

Utrujjah Dwi N, Masyithah. "PostKriminalitas Korupsi Hambalang”, http://www.negarahukum.com/huk um/post-kriminalitas-korupsihambalang.html, Diakses 17 Oktober 2012.

Mui/ira, "Sebagian Koruptor yang Diputus Bebas, Kena di Tingkat Kasasi, http://www.jambiindependent.co.id /j io/index.php?option--com content\&view--article\&id= 170 81, Diakses 31 Oktober 2012.

Sirait, Nikky, "Awas, Dibandingkan Demokrat, Nasib Golkar BisaLebih Terpuruk"http://jaringnews.com/po litikperistiwa/umum/1 8368/awasdibandingkan-demokrat-nasib- 
golkar-bisa-lebihterpuruk, Diakses 1 Oktober 2012.

Baren, Oki. "Tuntutan Turunkan SBYBoediono Disuarakan di KPK”, http://www.aktual.co/hukum/18054 6tuntutan-turunkan-sby-boedionodisu,qrakan-di-kpk, Diakses 31 Oktober 2012.

Untoro, Ons, "Sebutir Kejujuran Ditengah Kepalsuan",http://www.tembi.net/i d/news/beritabudaya/sebutirkejujur an-ditenga'hkepalsuan-1506.html, Diakses 17 Oktober 2012.

Risnawati,"Menko Polhukam: Gugatan Polrike KPK Bukan

Bentuk Perlawanan", http://indonesiarayanews.com/news /hukum-kriminal/ 10-30-2012-0944/menko-polhukam-gugatan-polrike-kpk-bukan-bentuk-perlawanan,

Diakses 31 Oktober 2012.

Saleum,Tal,http://beritakorea.com/917349, Diakses 31 Oktober 2012.

Puji rahayu, Santi'Mendukung PemberantasanKorupsi ",http:Hsur at-pembaca-jumalismewarga.pelitaonline.com/news/2012/ 09/07/mendukung-pemberantasankorupsi\#.UH4Up9luWiY, Diakses 17 Oktober 2012.

Sudjito, "Chaos Theory Of Law: Penjelasan atas Keteraturan dan Ketidakteraturan dalam Hukum", Mimbar Hukum Vol. 18, No. 2, (Juni 2006), Diakses 31 Oktober 2012.

Artandi, Tom,'Topeng Kepalsuan dalam Kehidupan Kita," http: //sosbud.kompasiana.com/2012/09/ 04/topeng-kepatsuan-dalamkehidupan-kita/, Diakses 17 Oktober 2012.

Wikipedia Bahasa Indonesia, Ensiklopedia Bebas (1), Undang-Undang Dasar Republik Indonesia 1945, http://id.wikipedia.org/wiki/TJndan gUndang_Dasar-Republik-
Issn cetak 2597.9353 Issn online 2580.6319 Vol 1. No. 2 Desember 2017

Indonesia-1945, Diakses 23 April 2009.

-(2), Tari Topeng, http:// id.wikipedia.org/wiki/Tari_Topeng, Diakses 31 Oktober 2012.

Sembodhro, Woro,"Maaf, Rakyat Sudah MuakDenganKepalsuan'http://sura tpembacajurnalisme-warga.pelitaon line.com/news/2012/09/12/maaf rakyat-sudah-muak-dengan kepalsuan\#.UH4TBdluWiY, Diakses 17 Oktober 2012.

Winarto, Yudho" Kompolnas desak Korlantas cabut gugatan ke KPK, http://nasional.kontan.co.id/news/k ompolnas-desak-koriantas-cabut gugatanke-kpk/2012/10/30,Diakses 31 Oktober 2012.

Amandemen ke-3 UUD 1945.

Kabari, Tari Topeng Multi Karakter, http://kabarinews.com/seni-tari topeng-multi-karakter/49755, Diakses 31 Oktober 2012.

Dedy Black, "Mundur dari DPRD Kota", http://harianrakyatbengkulu.com/de dy-black-mundur-dari-dprd-kota/, Diakses 17 Oktober 2012.

PKS Sebut Kepalsuan, Pemberantasan Korupsi Runtuhkan Citra SBY, http://pksplajupalembang.blogspot. com/2012/01/pks-sebut-kepalsuanpemberantasan.html, Diakses 17 Oktober 2012.

Menguak "Bungkus Kepalsuan Partai Penguasa",http://kabamet.wordpre ss.com/2012/02/01/menguakbungkus-kepalsuanpartai penguasa/, Diakses 17 Oktober 2012.

Layak DPR Menjadi Musuh Seluruh Rakyat," http://www.voaislam.com/news/opini/2012/09/27/ 20889/layak-dpr-menjadi-musuliseluruhrakyat/, Diakses 1 Oktober 2012.

Tari Topeng Topeng dan Kebudayaan, http://www.anneahira.com/tari- 


\section{Issn cetak 2597.9353 | Issn online 2580.6319}

Vol 1. No. 2 Desember 2017

topeng.htm, Diakses 31 Oktober 2012 http://www.bab5warg4_negar"andan_nega ra.pdf, Diakses 28 Desember 2009 